\title{
Secondary school teachers' and pupils' definitions of bullying in the UK: a systematic review
}

\section{Niamh O’Brien}

This is a post-peer-review, pre-copy edited version of an article published in Evidence and Policy. The definitive publisher-authenticated version: O'Brien, N., 2009. Secondary school teachers' and pupils' definitions of bullying in the UK: a systematic review. Evidence and Policy, 5(4), pp.399-427 is available online at: www.ingentaconnect.com/content/tpp

The aim of the systematic review (SR) reported in this article was to compare how UK secondary school pupils and teachers define bullying, using the analytical framework proposed by Naylor et al (2006). Findings were drawn from five major studies - two quantitative, two qualitative and one using mixed methods - and suggest that teachers are much more likely than pupils to employ broader definitions and to include indirect forms of bullying. Possible additions to Naylor et al's framework are highlighted. The SR encompassed views from 3,283 pupils and 225 teachers, and a number of modest implications for policy and practice are identified.

\section{Rationale}

No robust national statistics exist for reported cases of bullying in schools and this is, to a large extent, relates to the absence of an agreed definition of bullying with debate continuing over where acceptable 'playground behaviour' ends and bullying begins (OFSTED, 2003). Problems with definition and consequent difficulties in recognition constitute the first barrier to dealing effectively with bullying (House of Commons Education and Skills Committee, 2007). A definition incorporating the views of both teachers and pupils could be considered as the first step in the development of workable anti-bullying strategies.

This systematic review (SR) was carried out in order to compare the definitions that UK secondary school teachers and pupils respectively assign to bullying. A previous scope review did not reveal any similar SRs addressing this substantive area and a SR was regarded as an appropriate way to bring together findings already extant into one combined study. It was thought that such a study, undertaken within the confines of a Master's degree dissertation, would have the potential to make a modest contribution to current knowledge of the formulation, implementation and evaluation of school anti-bullying policies.

\section{Background}

Most research conducted into how UK pupils define bullying has been carried out since the 1980s and reveals that, although pupils' definitions of bullying include aspects of both verbal and physical abuse, fewer references are made by them than by their teachers to social exclusion (Naylor et al, 2001). Differences related to the pupil's age are also reported. An example can be seen in the study undertaken by Smith et al (2002) who examined the terms used to identify bullying behaviour across 14 countries. The findings indicated that eightyear-olds did not distinguish as clearly between different forms of behavioural aggressions as did 14-year-olds.

The Department of Education and Skills (DfES), in its 2004 Don't suffer in silence pack, offered the following definition of bullying:

Repetitive, wilful or persistent behaviour intended to cause harm, although one-off incidents can in some cases also be defined as bullying: intentionally harmful behaviour, carried out by an individual or a group; and an imbalance of power leaving the person being bullied feeling defenceless. Bullying is emotionally or physically harmful behaviour and includes: namecalling; taunting; mocking; making offensive comments; kicking; hitting; pushing; taking belongings; inappropriate text messaging and emailing; sending offensive or degrading images by phone or via the internet; gossiping; excluding people from groups and spreading hurtful and untruthful rumours. (DfES, 1994, reported in House of Commons Education and Skills Committee, 2007,pp7-8) 
The Education and Skills Committee's report points out that this definition is consistent with the views of children and young people (referred to hereafter as children), with mainstream research in the field and with definitions from the Anti-Bullying Alliance and OFSTED (House of Commons Education and Skills Committee, 2007). The report highlights the fact that direct bullying, in the form of physical abuse, is easier to identify in terms of the actions of the perpetrator and the effects it has on the victim. Verbal bullying and forms of social exclusion (such as barring someone from a group or spreading unpleasant rumours about them) is much harder to identify and to control.. Furthermore, some behaviour officially regarded as bullying may not be viewed as such by those involved (House of Commons Education and Skills Committee, 2007).

This is similar to Boulton and Flemington's (1996) finding, based on a study of the effects of a single viewing of an anti-bullying videotape on secondary school pupils' views of, and involvement in, bullying. Overall, the research found little evidence of an effect, measured using a questionnaire before and after viewing the videotape. However, after watching the videotape, more pupils indicated that they would include 'name-calling, telling nasty stories and forcing people to do things they don't want to do' (Boulton and Flemington, 1996). However, the questionnaire left no room for pupils to put forward their own definitions of bullying, and the validity of some of the findings may therefore reasonably be questioned.

Based on research in an English secondary school, Lines (1999) argues that name-calling is a damaging form of bullying. The study questionnaire included space for pupils to add their own derogatory terms to the name-calling list and sexual words scored highly, as well as those that demeaned an individual's intelligence, 'put down' high achievers and concerned personal appearance. Terms associated with the family, specifically the mother, caused great distress. Some respondents had felt compelled to resort to complex defensive behaviour to deal with name-calling, despite such behaviour not having worked previously. Lines maintains that this indicates a high level of irritation and confusion among these pupils and suggests that there is a need for an intervention programme that is more gradually introduced than those currently used in secondary schools.

OFSTED (2003) carried out a survey in 2001-02 based on school inspectors' visits to a number of local education authorities and schools. This focused on strategies adopted by schools to reduce incidents of bullying, support victims and deal with perpetrators, and discussions were held with staff, pupils, parents and governors. The study revealed that, although they can occur together, there is a clear distinction between physical and verbal bullying (although the latter can lead to violence). Direct, physical bullying and the threats associated with it (including theft and damage to property) are more commonly used by boys, while verbal threats and manipulation are more characteristic of girls, with name-calling (often via modern communication media such as mobile phones or email) the most common form. Both types of bullying are largely concerned with the demonstration of power, and are used to create fear. The authors found that bullying, in relation to social exclusion, is often difficult to define and detect, and that such bullying can be focused on 'more or less anything that distinguishes an individual and represents a deviation from a presumed 'norm' (OFSTED, 2003, p4).

On the basis of an extensive library and electronic search by the author, only one study exclusively considering UK school teachers' definitions of bullying could be located. Boulton (1997) conducted bullying research with teachers from preschool through to secondary school, in part to establish what behaviours teachers perceived as bullying. He found that teachers tended to have a broader concept of bullying than their pupils, with behaviours such as 'threatening people verbally', 'hitting, pushing and kicking' and 'forcing people to do things they don't want to do' being highly rated. Other behaviours such as 'leaving people out' and 'laughing at someone's misfortune' received lower ratings. These findings suggest that bullying has been perceived by teachers as being more about physical and psychological power than social exclusion (Boulton, 1997).

An American study by Craig et al (2000), in relation to prospective teachers' attitudes towards bullying, revealed that physical bullying was viewed as more serious and more worthy of 
intervention than verbal bullying. Furthermore, less than half of the respondents regarded social exclusion as bullying.

The literature is awash with definitions of bullying (Olweus, 1995; Glover et al, 2000; Morrison, 2002; Juvonen et al, 2003; Alexander et al, 2004; Rigby, 2004; Sullivan et al, 2004) and the lack of consensus has been noted by, among others, the British Psychological Society (House of Commons Education and Skills Committee, 2007). Lee (2006) reports that much of the research in this field assumes that the definitions of bullying offered are in line with what participants think and that they will be able to place their own experiences within the framework presented to them. However, Sullivan et al (2004) argue that the bullying experience is specific to the individual in terms of what they deem to be important, as well as the circumstances and context of the particular event. Interestingly, this is true not just of the bullied, but also of the bully and the bystander. It follows that, while research can allow us to make generalisations about the rates, characteristics and causes of bullying, it 'can never mitigate against actual bullying events, can never predict who will bully and how, and cannot determine who will be a victim and why' (Sullivan et al, 2004, p6).

For decades, bullying has been seen as a taboo but it is now much more openly discussed (Smith, 1999) and prominent on the educational agenda in school, media and government arenas (Lee, 2006). It is important for schools to consider carefully their own criteria for the intervention they intend to adopt because 'persistent and concerted action on their part can diminish the problem of school bullying, and thereby enhance the rights, happiness and welfare of pupils in the foreseeable future' (Smith, 1999, p86). However, the Children's Commissioner for England has argued that 'despite good work in schools, there is still denial about the "existence, severity and effect" of bullying' (BBC News, 2005). As Boulton and Flemington (1996) point out, schools could feel overwhelmed by the vast amount of research, guidance and resources available.

One way of overcoming this problem could be to ask pupils how they define bullying, with the intention of developing policies that embrace the views and opinions of those at the receiving end. Involving the whole school community in participatory research would be one way to achieve this. Such an approach demonstrates an acceptance and understanding of children's rights where children are no longer viewed as passive recipients of adult socialisation but recognised as social actors in their own right (O'Kane, 2000; Willow, 2002). The approach is supported by Article 12 of the United Nations convention on the Rights of the Child (UNCRC), which stresses the importance of a child's right to have their opinion heard and taken into consideration in issues affecting their life.

As a result, this SR aimed to uncover research - published or unpublished - that sought to document secondary school pupils' and teachers' definitions of bullying in the UK, with an eye to the possible similarities and differences that might exist between them. Although large UK studies have considered these issues to some extent in primary schools (see, for example, Smith and Shu, 2000; Wolke et al, 2001; Jennifer et al, 2006), this study focused solely on secondary schools.

\section{Methodology}

The Critical Reviews Advisory Group (1996) points out that a SR, if rigorously performed, can have enormous value as a means of bringing together an array of separately conducted studies, some possibly showing conflicting findings, and synthesising their results. SRs have also been described as 'fit for purpose' in answering specific questions and testing hypotheses, rather than simply summarising all there is to know about a particular issue (Petticrew and Roberts, 2006). The ideal characteristics of a SR, although more commonly discussed in the health arena, are now well established in social policy and educational research (Torgerson, 2003). Evans and Benefield (2001), Margarey (2001) and Dixon-Woods et al (2005a) describe these as follows:

- They have an explicit study protocol addressing a highly focused pre-specified question; this question is generally narrow in its focus in order for it to be feasible to search for the required research. 
- Explicit methods are used by reviewers in order to search for studies.

- Explicit inclusion and exclusion criteria are set.

- An appraisal is conducted to determine the relevance of the studies to the review question and to determine their scientific quality; this is preferably carried out by two of more reviewers in order to eliminate bias.

- Explicit methods are used to combine findings across a range of studies. 
This SR included both quantitative and qualitative studies and data were synthesised using a thematic analysis. While Torgerson (2003) highlights the advantages of a quantitative approach, Evans and Benefield (2001) suggest that studies from both the quantitative and qualitative paradigms should be included. Although this study mainly considered views in relation to the notions held by secondary school pupils and teachers on bullying, Harden et al (2004) propose that research on people's views need not always use a qualitative methodology and that, often, a mixed approach is required. A decision was therefore made from the outset to ensure that all studies investigating the definitions that pupils and teachers at secondary schools in the UK attribute to bullying were included.

\section{Searching the literature}

As no SR had been carried out previously on this topic (evidenced from a scope review carried out beforehand), it was initially decided to look for research as far back as the 1970s, when the interest in bullying in schools reportedly began (Smith, 1999). With this in mind, a protocol was developed that outlined the search terms, the inclusion and exclusion criteria, and the data extraction and synthesis methods needed to answer the research question.

Many sources, such as electronic databases and relevant websites, were searched. The database search was undertaken using the Anglia Ruskin University search engine driven by Exlibris Metalib. This tool is used to cross-reference databases to which the university subscribes. The phrases used for this search are listed in Box 1 . Since many of the databases searched cover areas irrelevant to this research, the list of searched databases includes only those that gave positive results. Key journals were also scanned and 16 key professionals in the field of academia and practice were contacted to identify any 'grey' literature, ongoing studies or missed texts.

A large number 9379) of documents was located, which was beyond the resources of the project undertaken as part of an MSc award, so it was decided to limit studies to those more recently published. The year 1999 was chosen because the law on anti-bullying policies for all schools came into effect in November of that year (Smith and Samara, 2003) and it was felt that a higher awareness of bullying would have become apparent at that time.

The titles of each text were screened to check whether they met the inclusion criteria of:

- UK-based research both published and unpublished;

- research reported in the English language;

- secondary school research;

- good-quality methodology;

- not restricted to a focus on one particular group;

- studies reported since 1999.

Studies with significant results are more likely to be published so it is important to include unpublished studies in order to avoid publication bias (Beverley et al, 2006). In order to ensure that every possible piece of research was located, contact was made with key writers in the field and this identified one unpublished study, which was included in the review.

Table 1 summarises the flow of papers through the search and screening process. Of the 379 studies initially identified by the search strategy, 275 studies were rejected on the basis of their title, 62 on the basis of the abstract and 19 on the basis of being reported before 1999. Following this process, the remaining 23 papers were read in full and 18 were rejected as they did not meet the inclusion criteria. Table 2 indicates how they were searched and screened, resulting in the identification of only five research papers as meeting all the inclusion and exclusion criteria. 


\section{Box 1: Databases and search terms}

Databases searched:

- British Education Index, 1975 to date

- Web of Science via the Web of Knowledge

- The search engine Google

- The search engine Google scholar

To ensure that no grey or unpublished research was missed, the following websites were also searched:

- The National Youth Agency:

www.nya.org.uk/Homepage.asp?NodelD=88833 (accessed 6 February 2007

- Barnardo's:

www.barnardos.org.uk/resources/research and tips.htm (accessed 6 February 2007)

- The Children's Society www.childrenssociety.org.uk/ (accessed 6 February 2007)

- The Children's Rights Alliance for England www.crae.org.uk/cms/index.php?option=com frontpage\&ltemID=1 (accessed 6 February 2007)

- The following anti-bullying websites: www.beatbullying.org/docs/toolkits.html (accessed 6 February 2007) www.anti-bullyingalliance.org.uk/Page.asp (accessed 6 February 2007) www.anti-bullying.co.uk/ (accessed 6 February 2007) www.teachernet.gov.uk/wholeschool/behaviour/tacklingbullying/ (accessed 6 February 2007)

- The Office of the Children's Commissioner for England www.childrenscommissioner.org/adult/ccnews/publications.cfm?id=1970 (accessed 6 February 2007)

The following search terms were used:

- bullying

- bullying definitions

- young people's bullying definitions

- bullying and young people in secondary schools

- bullying and pupils in secondary schools

- bullying in secondary schools

- secondary school teachers' definitions of bullying

- similarities between teachers' definitions of bullying

- differences between teachers' and pupils' definitions of bullying 
Although only five studies met the inclusion criteria, the SR included the views of 3,283 students and 225 teachers together in one study. As a result, the variables of age and sex could be considered, at least to some extent, in the bullying definitions.

\begin{tabular}{|c|c|c|c|}
\hline $\begin{array}{l}\text { Number } \\
\text { of } \\
\text { articles }\end{array}$ & $\begin{array}{l}\text { Number } \\
\text { rejected }\end{array}$ & Reasons for rejection & $\begin{array}{l}\text { Number } \\
\text { remaining }\end{array}$ \\
\hline 379 & 275 & $\begin{array}{l}\text { Rejected at title: } \\
\text { Title not relevant to this study (104); focusing on one } \\
\text { particular group (48); non-UK study (36); duplicate (33); not } \\
\text { research (28); non-secondary school study (26) }\end{array}$ & 104 \\
\hline 104 & 19 & Rejected pre-1999: 19 & 85 \\
\hline 85 & 62 & $\begin{array}{l}\text { Rejected at abstract: } \\
\text { Paper not relevant to SR question (35); non-UK study (24); } \\
\text { primary school study (2); staff room bullying (1) }\end{array}$ & 23 \\
\hline 23 & 18 & $\begin{array}{l}\text { Rejected when the full papers were examined: } \\
\text { Non-UK study (8); pre-1999 study (2); study focuses } \\
\text { specifically on name-calling (1); study looks at the extent to } \\
\text { which self, peers and teachers regard victims of bullying as } \\
\text { have poorer social skills than non-victims (1); study } \\
\text { investigates young people's experience of participating in a } \\
\text { peer support scheme to combat bullying (1); focusing } \\
\text { specifically on racial bullying (1); primary school study (1); } \\
\text { focusing on coping strategies and attitudes towards school- } \\
\text { based interventions in England and Japan (1); theoretical } \\
\text { approach to bullying (1); study incorporating } 14 \text { countries } \\
\text { considered too broad (1) }\end{array}$ & 5 \\
\hline
\end{tabular}

The depth of data and analysis in the included studies varied, as was the case with Harden et al's (2004) review. While some studies simply showed the range of pupils' views in relation to bullying definitions, others identified reasons for these differences (sex, age, for example) and others examined coping strategies (although this SR did not include this element). Like Harden et al's review, a broad range of studies was included, from a small-scale, qualitative study involving 70 pupils and no teachers (Thomson and Gunter, unpublished) to a largescale, quantitative study including 1,820 pupils and 225 teachers (Naylor et al, 2006).

\section{Quality assessment}

In order to ensure that the studies selected for this SR were rigorous in terms of their reliability and validity, in addition to being ethically sound, a checklist was developed to in order to assess each piece of research. The use of a checklist ensures that the main methodological issues are examined systematically, using the same approach for each study, thus ensuring that problems or biases are less likely to be ignored (Petticrew and Roberts, 2006). A convincing rationale for using a quality assessment tool is provided by Harden et al (2004), who document the difficulties experienced in judging whether aspects of a study are 'clear', 'explicit' or 'sufficient'.

The chosen checklist adapted from Booth (2006) included four main sections:

- aims and objectives of the study;

- data collection and analysis, including research design and setting, sampling strategy, data collection methods and data analysis;

- ethical issues, including informed consent, freedom from harm and anonymity;

- how the study relates to the body of knowledge.

Rating criteria were used, which assigned each study one point for each aspect of the quality assessment, including the subcategories, making a maximum total score of nine. Appropriate methods for appraising research very across the disciplines and it was therefore important to 
adjust the checklist accordingly to ensure that all elements needed for assessing the quality criteria were considered (Petticrew and Roberts, 2006). Table 2 details the studies included in this quality assessment.

The literature suggests that SRs should be carried out by a team of researchers, in order to ensure that nothing is missed and to minimise reviewer bias (Evans and Benefield, 2001); Khan et al, 2001; Torgerson, 2003; Harden et al, 2004; Beverley et al, 2006; EPPI-Centre, 2006). For example, Khan et al (2001, p8) point out that it is generally accepted that unmasked independent quality assessment by more than one reviewer should be sufficient in making judgements about study quality'. In this review, the retrieval and sifting of data, quality assessment, data extraction and data synthesis were all carried out by one reviewer, due to the MSc programme constraints, which could be classified as a disadvantage.

Research shows that a further way to remove bias in a SR is through blinding, where the reviewer reviews a research paper while not being aware of who the authors are (Khan et al, 2001; Torgerson, 2003). Again, this was not possible in this case. However, it was felt that contacting the authors of each study after the quality assessment had been carried out would enhance rigour. The five authors were sent their respective, completed quality assessments to ensure that nothing was missed and that the assessment was as free from researcher bias as possible.

\section{Data Analysis}

A thematic approach was used to analyse the data. Although thematic analysis is more familiarly employed in qualitative research, there are compelling arguments to support its use in quantitative research. For example, variables included in surveys can be extracted as 'themes' in a similar way that conceptual themes are extracted from qualitative research data (Dixon-Woods et al, 2005b; Popay et al, 2006).

However, there are problems with thematic analysis when used in a SR. These difficulties are associated with lack of transparency as it can be difficult to identify how and at what stage themes are identified (Dixon-Woods et al, 2005b). For this reason, care was taken to specify why particular themes were chosen during the analytical process (Byrne, 2001). A further limitation of this approach is that it is not always clear whether the analysis should focus on the frequency of the emerging themes or those themes with a high level of explanatory value (Dixon-Woods et al, 2005b). Moreover, Dixon-Woods et al (2005b, p47) contend that thematic analysis offers little in terms of theoretical structure for reviewers to develop 'higher order thematic categories beyond those identified from the literature'. In order to overcome this, Popay et al (2006) suggest that reviewers provide as much detail as possible about how a thematic analysis was conducted.

In order to compare teachers' and pupils' definitions of bullying, themes that had been used previously by researchers to depict teachers' definition were first used. From the five studies, only one considered teachers' views (Naylor et al, 2006) so, in order to incorporate these views, the thematic analysis was initially arranged around these themes. However, throughout the analytical process, new themes were developed and existing ones adapted in order to ensure that all the data were accounted for. Once data were re-examined for a second time, sub-themes began to emerge and a clearer picture of the data began to emerge. Naturally, more data had been made available in relation to the pupils' definitions than the teachers' so the similarities and differences that emerged under each theme were considered together.

\section{Reflections on the SR methodology}

The five studies employed different methodologies to find a definition of bullying and this hindered comparison between them. Nevertheless, thematic analysis has made some comparison possible because it can be used for both qualitative and quantitative studies. The decision to analyse journal articles rather than searching for a full research report for the articles found caused a number of problems. Sometimes there was insufficient detail about the methodology and/or the study context. Similarly, ethical issues were not always given 


\begin{tabular}{|c|c|c|c|}
\hline & $\begin{array}{l}\text { Naylor et al (2006): Teachers' and pupils' } \\
\text { definitions of bullying }\end{array}$ & $\begin{array}{l}\text { Thomson and Gunter (unpublished): } \\
\text { Researching bullying with students: a lens on } \\
\text { everyday life in an innovative school }\end{array}$ & $\begin{array}{l}\text { Oliver and Candappa (2003): Tackling } \\
\text { bullying: listening to the views of children } \\
\text { and young people }\end{array}$ \\
\hline Type of study & Quantitative study with a qualitative aspect & Qualitative study & Mixed methods \\
\hline Aim of study & $\begin{array}{l}\text { To investigate gender and teacher/pupils status, } \\
\text { and with pupils to examine their bullied status } \\
\text { and age in relation to the definitions they assign } \\
\text { to bullying }\end{array}$ & $\begin{array}{l}\text { Working with a group of student researchers at } \\
\text { secondary school to research issues of bullying } \\
\text { and safety }\end{array}$ & $\begin{array}{l}\text { To explore children's experiences of bullying } \\
\text { and to investigate how successful or otherwise } \\
\text { they felt interventions were - children's } \\
\text { definitions of bullying was part of this study }\end{array}$ \\
\hline Sample number & 2,045 teachers and pupils & $\begin{array}{l}14 \text { focus groups randomly selected from each } \\
\text { year }\end{array}$ & 953 primary and secondary school pupils \\
\hline Sample type & $\begin{array}{l}225 \text { teachers ( } 158 \text { women and } 67 \text { men) and } \\
1,820 \text { pupils ( } 466 \text { boys and } 460 \text { girls in Year } 7 \\
\text { and } 415 \text { boys and } 479 \text { girls in Year } 9 \text { ) }\end{array}$ & $\begin{array}{l}\text { Three focus groups from each year level with the } \\
\text { exception of Year } 7 \text { which had two. Each group } \\
\text { had } 4-5 \text { participants }\end{array}$ & $\begin{array}{l}779 \text { pupils in Year } 8 \text { and } 174 \text { pupils in Year } 5 \text {. } \\
\text { In total } 500 \text { girls and } 444 \text { boys took part. In } 9 \\
\text { cases the gender of the pupil was not given }\end{array}$ \\
\hline Age & $\begin{array}{l}\text { No age given for teachers. Pupils aged 11-14 } \\
\text { years }\end{array}$ & Not given & $\begin{array}{l}\text { Year } 8 \text { pupils average age } 12 \text { years, Year } 5 \\
\text { pupils average age } 9 \text { years }\end{array}$ \\
\hline Data & $\begin{array}{l}\text { Written questionnaire response to one question: } \\
\text { 'Say what you think bullying is.' These were } \\
\text { content analysed }\end{array}$ & $\begin{array}{l}\text { A set of questions were drawn up for the focus } \\
\text { groups and a number of staged photographs } \\
\text { representing ambiguous peer interactions were } \\
\text { used as triggers in discussions }\end{array}$ & $\begin{array}{l}\text { Views and experiences investigated using both } \\
\text { qualitative (focus groups) and quantitative } \\
\text { (questionnaire survey) methods. } \\
\text { Questionnaire survey was designed to explore } \\
\text { quantitatively some of the themes raised by the } \\
\text { focus group - one such question was around } \\
\text { children's definitions of bullying }\end{array}$ \\
\hline Context & $\begin{array}{l}51 \text { secondary schools across the UK - mainly } \\
\text { England, each with peer support systems to } \\
\text { counteract bullying established for at least a year }\end{array}$ & $\begin{array}{l}\text { School is set in one of the wealthiest locations in } \\
\text { the North of England. Did not state if it had an } \\
\text { anti-bullying policy }\end{array}$ & $\begin{array}{l}12 \text { schools selected using purposive sampling } \\
\text { ( } 6 \text { primary and } 6 \text { secondary schools). Selected } \\
\text { in relation key variables know to have an } \\
\text { impact (or potential impact) on bullying, ie } \\
\text { school size, geographical location, status as } \\
\text { co-educational or single sex and religious } \\
\text { affiliation. Participating schools were located } \\
\text { in Leeds ( } n=4) \text {, East Sussex ( } n=3) \text {, Islington } \\
(n=2) \text { and Lambeth }(n=3)\end{array}$ \\
\hline Key findings & $\begin{array}{l}\text { Teachers express more comprehensive ideas in } \\
\text { their definitions of bullying while pupils are more } \\
\text { likely to limit their definitions to direct bullying } \\
\text { (verbal/physical abuse) and are less likely to } \\
\text { refer to power imbalance, social exclusion or the } \\
\text { bully's intention to cause hurt or harm. } \\
\text { Teachers need to listen to what pupils have to } \\
\text { say about bullying and work with them to help } \\
\text { them develop their ideas around the issue. } \\
\text { Furthermore, some teachers need to develop } \\
\text { their own conceptions of bullying }\end{array}$ & $\begin{array}{l}\text { Student researchers and those involved as } \\
\text { respondents all had very broad definitions of } \\
\text { bullying. They included aspects of focusing on } \\
\text { differences, particularly in relation to clothing and } \\
\text { shoes and exclusion of students from groups } \\
\text { both within and outside the classroom. Aspects } \\
\text { around 'pushing, kicking, happy slapping and } \\
\text { texting' arose from the focus groups. For the } \\
\text { student researchers they found that bullying was } \\
\text { more common for younger students than older } \\
\text { ones }\end{array}$ & $\begin{array}{l}\text { Pupils provided clear and comprehensive } \\
\text { definitions of bullying covering a broad } \\
\text { spectrum such as verbal and physical abuse, } \\
\text { theft, threatening behaviour, coercion, } \\
\text { behaviour intended to cause distress or harm } \\
\text { and the negative impact it can have on well } \\
\text { being and personal safety. Vulnerability was } \\
\text { seen in relation to differences such as physical } \\
\text { size or appearance, or even racism, sexism, or } \\
\text { homophobia }\end{array}$ \\
\hline
\end{tabular}




\begin{tabular}{|c|c|c|}
\hline & $\begin{array}{l}\text { Monks and Smith (2006) Definitions of bullying: age } \\
\text { difference in understanding of the term, and the role of } \\
\text { experience }\end{array}$ & $\begin{array}{l}\text { Boulton et al (2002) Associations between secondary school } \\
\text { pupils' definitions of bullying, attitudes toward bullying and } \\
\text { tendencies to engage in bullying: age and sex differences }\end{array}$ \\
\hline Type of study & Quantitative study & Quantitative study \\
\hline Aim of study & $\begin{array}{l}\text { Two studies were conducted to examine children's definitions of } \\
\text { bullying. The first study compared this understanding among } \\
\text { children aged } 4-6 \text { years, children aged } 8 \text { years, adolescents } \\
\text { aged } 14 \text { years, and parents. The second study examined this in } \\
\text { more detail with } 4-6 \text { year olds. As a result this review is only } \\
\text { concerned with the first study }\end{array}$ & $\begin{array}{l}\text { To extend researcher knowledge of bullying in } 5 \text { ways: (1) age and } \\
\text { sex differences in specific types of bullying activities; (2) age and } \\
\text { sex differences in pupils' views concerning which behaviours } \\
\text { are/are not bullying; (3) associations between pupils' definitions of } \\
\text { bullying and self-reported bullying behaviour; (4) age and sex } \\
\text { differences in attitudes towards bullying; (5) associations between } \\
\text { pupils' attitudes and self-reported bullying behaviour (p356) }\end{array}$ \\
\hline Sample number & 40 participants & 170 pupils \\
\hline Sample type & 20 boys and 20 girls & $\begin{array}{l}82 \text { girls and } 88 \text { boys selected at random from } 2 \text { registration classes } \\
\text { from Years } 7 \text { to } 10\end{array}$ \\
\hline Age & 14 year olds & Mean ages given as $11.5-14.5$ years \\
\hline Data & $\begin{array}{l}\text { Pupils were given } 17 \text { cartoons that came from a larger set of } 25 \\
\text { used by Smith et al in } 2002 \text {. This group of pupils had initially } \\
\text { been assessed as part of two other studies (Smith et al 2002; } \\
\text { Smorti et al 2003). They had to read the captions on the } \\
\text { cartoons and divide them into two piles with the heading 'this is } \\
\text { bullying' or 'this is not bullying' }\end{array}$ & Self-report questionnaire \\
\hline Context & $\begin{array}{l}\text { All participants were from urban schools in the London area. Did } \\
\text { not specify if anti-bullying policy was in place }\end{array}$ & $\begin{array}{l}\text { One secondary school in semi-rural location in the UK. The school } \\
\text { had not implemented any specific anti-bullying intervention at the } \\
\text { time of the study. Classes selected were mixed in ability }\end{array}$ \\
\hline Key findings & $\begin{array}{l}\text { This age group ( } 14 \text { year olds) had 'more differentiated } \\
\text { conceptualisation of bullying' ( } \mathrm{p} 811) \text { using two dimensions to } \\
\text { differentiate between bullying behaviours. They also } \\
\text { distinguished between physical and non-physical behaviours (eg } \\
\text { verbal aggression or relational/social aggression) }\end{array}$ & $\begin{array}{l}\text { Most of the pupils involved did not share the same views as adults } \\
\text { about what constitutes bullying behaviour. Most saw hitting and } \\
\text { pushing, threatening someone and coercion and to a lesser extent } \\
\text { telling nasty stories about someone, calling people nasty names } \\
\text { and stealing as types of bullying. Fewer pupils saw social } \\
\text { exclusion as a form of bullying. Boulton et al suggest that because } \\
\text { pupils don't view this behaviour as bullying could be a reason why } \\
\text { they behave in this way. No significant differences in age and sex } \\
\text { in the way pupils classified behaviours as bullying/not bullying. } \\
\text { These is a need to widen the conceptions that both boys and girls } \\
\text { have in relation to bullying and drama/role-play, curriculum work } \\
\text { and anti-bullying videos may help - although positive effects have } \\
\text { been modest. Most pupils expressed high levels of support for } \\
\text { victims of bullying and endorsed action against bullying; generally } \\
\text { they were not in favour or bullying }\end{array}$ \\
\hline
\end{tabular}


enough attention. Other SRs, carried out in relation to views and experience (Attree, 2004; Harden et al, 2004), have encountered the same difficulties. In order to clarify some of these issues, authors were contacted directly and asked to comment on the quality assessment process. One of the five corresponding authors revealed some surprise at what was reported and revisions were consequently made. On reflection, it appears that, had the full research report been made available, then questions about methodology, data collection and ethics could have been addressed. If this study was to be replicated, contact would need to be made with authors much earlier on and access to full reports secured. By the same token, the process of checking with authors has proved to be a valuable aspect of the review.

Finally, the literature search identified a number of papers relating to bullying in particular populations, such as those with learning difficulties, gay and lesbian young people, Gypsy/Traveller young people. While this study took a more general approach to bullying in the 'mainstream', a SR of bulling within these more specific areas could raise issues of wider interest.

\section{Findings}

Through the analytical process, nine major themes emerged about bullying definitions and, within these themes, the similarities and differences between teacher and pupil perspectives are now considered. As only one study - Naylor et al (2006) - considered teachers' views, it was decided to use these themes at the beginning of the analytical process. As a result, the first six themes (italicised) were derived from Naylor et al (2006) and the final three themes from the remaining studies:

- direct bullying;

- social exclusion;

- power imbalance;

- repetition;

- intending harm;

- how bullying affects the target;

- sexualised bullying;

- focus on difference;

- coercion.

\section{Direct bullying}

Not surprisingly, most participants in the five studies felt that physical and/or verbal abuse should be defined as a form of bullying. For example, Naylor et al (2006) found that $62 \%$ of pupils considered physical abuse in their definition and 60\% referred to name-calling. However, there is a difference between teachers and pupils in terms of how they define bullying. In Naylor et al's study, for teachers, $10 \%$ of males and $10 \%$ of females focused on bullying in its direct form in their definition while, for pupils, $35 \%$ of boys and $33 \%$ of girls constructed bullying in this way.

Here, the participant's sex does not appear to be an important variable, an interesting finding given that some studies have suggested that sex is associated with the use of bullying. For example, in terms of prevalence, Oliver and Candappa (2003) report that direct bullying, in the form of physical abuse, was higher for boys but that, on the whole, similar levels of namecalling for both sexes were apparent. Similarly, Thomson and Gunter (unpublished) found that physical abuse was more commonly used by boys than girls and that girls tended to use verbal abuse more often than boys. On the other hand, the studies by Boulton et al (2002) and Monks and Smith (2006) revealed no important differences in terms of sex.

Oliver and Candappa (2003) found that verbal abuse was the most common form of bullying in their study of pupils in Years 5 and 8 . Unpicking the detail from this study reveals a number of differences, however, according to the method of data collection employed. Homophobic name-calling, for example, was discussed in the focus groups but featured much less in the findings from the survey. In terms of seriousness, participants said that verbal 
abuse directed at the target's family was particularly upsetting. Thomson and Gunter (unpublished) reported that sexist and racist verbal abuse was considered to be a common aspect of bullying and that this was often focused on the target's clothing or footwear. They state that 'The data does suggest that social and cultural minorities in the school are more likely to be subject to the persistent name calling, isolation and minor physical scuffling the students regarded as bullying behaviour ( $\mathrm{p} 7)$.

Oliver and Candappa (2003) also found that racist verbal abuse appeared in the dfinitions of bullying offered by secondary school pupils.

\section{Social Exclusion}

This theme was included as an aspect of bullying by some participants in all five studies although, perhaps surprisingly, only $13 \%$ of teachers referred to social exclusion in their definition of bullying (Naylor et al, 2006). The proportion for pupils, in the same study, was even lower (6\%) although, arguably, this is far less surprising. However, the method used to collect data may also have an effect: $75 \%$ of participants in Monks and Smith's study (2006), for example, ranked the presented cartoon portraying social exclusion as bullying and, when indicators of aggression were added, $83 \%$ believed that bullying had occurred. In contrast, Boulton et al (2002) reported that only $20 \%$ of participants in their study considered 'leaving people out' as a form of bullying.

Interestingly, a pupil's age is an important variable but not, perhaps, in the direction expected. The proportion of pupils, overall, who embrace social exclusion within their definition of bullying is higher for the younger age range. Oliver and Candappa (2003) report that 'social isolation' was reported by both year groups studied - Years 5 and 8 - but more so by the former than the latter. Similarly, Monks and Smith (2006), when using their cartoon ' $X$ won't let $Y$ play today', found that more eight-year-olds (88\%) considered this to be bullying than did 14-year-olds (45\%). Boulton et al (2002) reported that the proportion of their participants in their study regarding 'leaving people out' as a form of bullying fell as the pupils got older: in Year $7,24 \%$ of girls and $30 \%$ of boys saw this as bullying but, by Year 10 , no girls and only $18 \%$ of boys regarded this behaviour as bullying. However, these differences must still be treated with caution because they have not been found in all the major studies. Naylor et al (2006), for example, reported the reverse, with more Year 9 than Year 7 pupils perceiving social exclusion as bullying.

\section{Power imbalance}

Although Oliver and Candappa (2003) did not analyse their findings on power imbalance further in terms of the child's age, the following words from an older participant are compelling: 'It happens when a group gang up on someone younger or someone new or weaker. They're not afraid of attacking them' (boy, Year 8; 2003, p41). Power imbalance was apparent as a theme in four of the five studies. For teachers, it was a major them, with $71 \%$ including power imbalance in their definition of bullying. For pupils, power imbalance tended to become more important with age. So, for example, in Naylor et al's (2006) study, more Year 9 than Year 7 pupils included power imbalance in their definition. In Monks and Smith's research (2006), 98\% of 14-year-olds considered power imbalance as a form of bullying, while $75 \%$ and $95 \%$ of four- to six-year-olds and eight-year-olds respectively allocated the power imbalance cartoons to the 'this is bullying' pile. However, findings from Boulton et al's (2002) study appear to reveal the opposite, with power imbalance - in the form of 'threatening people' - appearing more important for the younger age group ( $88 \%$ of girls and $78 \%$ of boys in Year 7 ) than the older age group (73\% of girls and $71 \%$ of boys in Year 10).

\section{Repetition}

In Naylor et al's (2006) study, $17 \%$ of teachers and $8 \%$ of pupils believed that bullying included repetition, while all those involved in the focus group element of Oliver and Candappa's (2003) study considered that bullying occurred over a period of time. Monks and Smith (2006) found that, when physical or verbal aggression was combined with repetition, 
more participants viewed this as a form of bullying than when repetition was absent. This was particularly so for verbal abuse. When repetition was added (' $X$ say nasty things to $Y$ everyday'), all 14-year-olds agreed that this was bullying whereas, prior to repetition being added, only $88 \%$ had agreed.

In relation to the pupil's age, Naylor et al (2006) and Monks and Smith (2006) reported different findings. Naylor et al (2006) found that more Year 9 pupils mentioned repetition in their bullying definitions than did Year 7 pupils. Conversely, Monks and Smith (2006) found that, although the proportion of 14-year-olds rose as a result of repetition being added - ' $X$ never lets Y play' - overall, more eight-year-olds (90\%) believed that actions needed to be repetitious before they could be viewed as bullying than did 14 -year-olds (75\%).

\title{
Intending harm
}

In Naylor et al's (2006) study, $25 \%$ of teachers believed that bullying intentionally causes hurt or harm and is defined as 'the wilful conscious desire to hurt, threaten or frighten someone, verbally, physically or mentally' (teacher: Naylor et al, 2006, p559). Fewer pupils mentioned the perpetrator's intentionality while, in Oliver and Candappa's (2003) study, participants acknowledge that verbal and physical abuse can have the same effect on a target simply because 'it hurts on the inside' (2003, p40). Thomson and Gunter (unpublished, p10) reported that 'the data suggested that there was no single perpetrator in this kind of bullying nor was there generally a malicious intent'. Furthermore, the student researchers involved in this study argued that bullying should be defined in relation to the effects it had on the target and not in relation to the behaviour of the bully. Monks and Smith (2006) reported that the issue of intentionality is considered much more by pupils as they get older ( $88 \%$ of 14 -yearolds compared to $60 \%$ of eight-year-olds). Although intention to cause hurt was only briefly considered by Oliver and Candappa (2003), the following constitutes a particularly succinct definition: 'Bullying is intentionally causing physical or mental damage to others, like attacking them for no reason frequently, teasing them frequently, or even sexually, such as rape' (girl, Year 8; Oliver and Candappa, 2003, p39).

\section{How bullying affects the target}

In terms of how bullying affects the target, in Naylor et al's (2006) study, in regard to feeling hurt and/or threatened, $76 \%$ of teachers included such feelings in their definition compared to only $31 \%$ of pupils. On close inspection, while 'feeling hurt' was mentioned proportionately more by teachers than by pupils (58\% of teachers and $28 \%$ of pupils), a much sharper difference could be seen in relation to the target 'feeling threatened', with $45 \%$ of teachers referring to this in their definition of bullying, compared to only $7 \%$ of pupils (Naylor et al, 2006). It is fair to suggest that, because threat is less visible than hurt, it is more likely to feature in teachers' and arguably, older pupils' definitions. Thomson and Gunter (unpublished, p10) state that:

\begin{abstract}
The student researchers were adamant that the everyday practices of name calling, isolation and physical interaction can be damaging, and long lasting even though those who suffer might put on a brave face and also engage in the very same practice towards others...The student researchers' and the focus groups' primary focus was on the victim(s) and their feelings. If the victim(s) felt intimidated, persecuted, belittled or unsafe through the regular occurrence of one or all of these small interactions, then they thought that bullying had occurred.
\end{abstract}

Although this theme was not mentioned explicitly by Oliver and Candappa (2003), the following quote shows how children consider the feelings of the target, at least to some degree:

Some people, like the boy who got thrown against the gate, is in a really bad way. He is very little and comes from a hopeless poor family. But they do get left alone when people realise they can't help it and are just hopeless. (boy, Year 8; Oliver and Candappa, 2003, p40). 
Boulton et al (2002) considered how the variables of age and sex are associated with how pupils perceive and behave towards the victims of bullying. The results are inconclusive with only narrow differences displayed, although there is a suggestion that older pupils are more likely to express support for victims: in Naylor et al's (2006) research, more Year 9 than Year 7 pupils considered the effects of bullying on the victim. In Year 7, females expressed more support for action against bullying than did boys, but in Years 9 and 10 this was reversed. Similarly, girls were more likely to be concerned with the effects that bullying has on the target than were boys. For teachers, the differences in terms of gender are also small: for example, $81 \%$ of males and $74 \%$ of females considered ways in which bullying affected the target, when providing their definition of bullying (Naylor et al, 2006).

The following three themes were not highlighted in the study by Naylor et al (2006), suggesting that they were also afforded less weight by teachers in their definitions of bullying. However, there is evidence to support their significance, at least to pupils, alongside the six themes identified by Naylor et al (2006). For the most part, the three themes were found in the qualitative and mixed methods studies, perhaps because participants in the quantitative studies were not given the option to put forward their own definitions but had to 'go with' what the researchers produced. This suggests a weakness in the validity of the quantitative studies as participants may have been unduly influenced by the terms used by researchers.

\section{Sexualised bullying}

Although it was not offered as an option in the two quantitative studies, sexualised bullying emerged as an important theme for pupils in the studies by Oliver and Candappa (2003) and Thomson and Gunter (unpublished). In the former, girls reported higher levels of sexualised bullying and $5 \%$ of pupils (mostly girls in Year 8 ) alleged that they had been touched in an unwanted sexual way. Thomson and Gunter (unpublished) showed that sexual harassment around clothing was common for girls and that: 'terms such as slut, ho, prostitute, and slag were commonly produced in response to particular items of clothing; the girls in the students' research team reported that these were terms in common use around the school'. In the context of research aimed at finding out how pupils define bullying, this appears to be an important discovery.

\section{Focus on difference}

Bullying is when someone picks on someone else because they are different - their race, height, weight, or looks... [it's about] prejudice and discrimination and when someone gets hurt physically or mentally, or when someone is not respected. (Oliver and Candappa, 2003, p41).

Thomas and Gunter (unpublished, p7) identified the particular importance of physical appearance in this context: 'an imperfection such as being overweight could lead to bullying'. Other key differences were having unusual footwear or clothes, sporting the wrong brand of trainers or showing obvious signs of poverty. Oliver and Candappa (2003) reported that more Year 8 than Year 5 pupils saw bullying to be targeting fellow pupils in this way. Academic high achievers were also included as likely targets: 'If you do a good piece of work, and you're really proud of it, and then they ruin it. And you get really upset' (girl, Year 5; Oliver and Candappa, 2003, p40); 'Bullying is ... calling clever children 'geeks' and forcing them to do your homework' (boy, Year 5; 2003,p40).

Thomson and Gunter (unpublished) also referred to academic high achievers and found that this aspect of bullying was more common in the definitions provided by junior pupils.

\section{Coercion}

Coercion emerged as a theme in two of the studies. Oliver and Candappa (2003) described how blackmail, theft and putting pupils under pressure can operate as characteristics of bullying behaviour. For Boulton et al (2002), coercion was one of the options offered to pupils, phrased as 'forcing people to do things they don't want to do', and, in this regard, more males $(85 \%)$ than females $(70 \%)$ considered this to be a form or aspect of bullying. 


\section{Discussion}

It is apparent, both from these five studies and from the wider literature, that there are differences in how pupils and teachers define bullying and that much of this is related to age and understanding. Furthermore, secondary school pupils are not an homogenous group in regard to understanding bullying. For example, 'social exclusion' was more likely to be defined as bullying by younger pupils, while 'power imbalance' tended to be more apparent in definitions as pupils became older. Although most of the studies gave details in terms of gender, age and school context, issues of ethnicity, lifestyle and home environment were not provided. These are significant omissions because all three issues can have a bearing on pupils' experiences and therefore their definitions of bullying. Like Attree (2004), this SR is nable to provide a detailed analysis of these factors and does not claim generalisability for its findings.

Across the five studies, physical bullying was more common among boys and verbal bullying more common among girls, and some of the wider literature supports these findings (Byrne, 1994; OFSTED, 2003). Smith et al (2002), on the other hand, reported no gender differences in relation to direct bullying. Boulton et al (2002) pointed out that, although a general trend exists showing this link between 'male' and 'female' bullying behaviour, there is a substantial proportion of pupils who do not follow these trends, perhaps suggesting that 'male' and 'female' bullying forms are not exclusive to gender. This raises key questions about defining bullying in secondary school.

Forms of social exclusion-as-bullying were considered in all the studies although, within the quantitative studies, the proportions of the samples including it were quite low. In the broader literature, Boulton (1997) found that terms relating to social exclusion received lower ratings by teachers - one in four did not regard spreading rumours or social exclusion to constitute bullying - and Craig et al (2000) found that, among prospective teachers, less than half regarded social exclusion as bullying. One of the studies - Naylor et al (2006) - revealed that the schools in question had a peer support system in place to deal with bullying. Woods and Wolke (2003) assert that when direct bullying is addressed, pupils may turn towards more concealed methods. It is possible that teachers are less aware of such behaviour and therefore do not include it in their definitions. As Thomson and Gunter (unpublished, p8) state, 'students were also able to change their tactics if challenged by a teacher to make it appear as if they had stopped, whereas in reality, they adopted another approach'.

Recent surveys of pupils suggest that school bullying is much more widespread than school staff and other adults believe (Naylor et al, 2001; OFSTED 2003). Direct bullying among secondary school pupils is well documented in the literature but social exclusion and related victimisation are rarely mentioned (Naylor et al, 2001). Furthermore, OFSTED (2003) reveals that bullying in relation to social exclusion is often difficult to define and detect. It is not unreasonable to suggest that pupils subjected to these forms of bullying might not even be aware that they are being bullied (Boulton and Flemington, 1996; Naylor et al, 2001). More research in relation to social exclusion and victimisation is needed in order to increase understanding of this phenomenon and inform recommendations for practice.

It is a child's fundamental right to feel safe and to be spared the humiliation associated with bullying (Olweus, 1995). Most importantly, it is clear that much bullying behaviour directly contravenes a child's right under Article 3 of the European Convention on Human Rights to be protected from torture, inhuman or degrading treatment (Furniss, 2000). The 2004 Children Act, passed under the auspices of Every child matters: Change for children (DfES et al, 2004), provides policy and legislation in England to focus services around the needs of all children, young people and their families (see also HM Treasury, 2003). This is supported by its five goals for all children to:

- be healthy;

- stay safe;

- enjoy and achieve;

- make a positive contribution; and

- achieve economic well-being. 
Bullying can affect children's potential to achieve each of these five goals (House of Commons Education and Skills Committee, 2007). Oliver and Candappa (2003) argue that schools could develop anti-bullying strategies on the basis of the experiences of those who have suffered bullying but this SR recommends that schools include the whole-school community, first to define bullying and then to consider the development of anti-bullying policies. This approach promotes the importance of listening to children. Research has shown that the involvement of children leads to better decision making, because it is more likely to be based on accurate information and therefore more likely to be implemented and to have beneficial outcomes (Thoburn, 1992; Hodgson, 1996). Children have indicated that they want to be involved in decisions about matters affecting them and, more importantly, they want to be listened to by adults (Moules and O'Brien, 2007). This involvement would ensure that bullying definitions and anti-bullying strategies are truly child-focused and thus much more likely to be effective (Oliver and Candappa, 2003). Additionally, such involvement can be extended across the boundaries of the school. The school is part of the wider community and could play a part in dissemination inclusivity further afield, thereby promoting the idea of community involvement in public decision making.

\section{Implications for practice}

This SR used the conceptual framework of Naylor et al (2006) but also recognised a further three themes identified by pupils. Issues around sexualised bullying, a focus on difference and coercion are considered important by pupils and will need to be taken into account within a whole-school definition of bullying. Through painstaking collaboration, teachers and pupils could work together to consider these issues, as well as others that might emerge, before moving on to produce their definition of bullying. Pupils will need support from teachers for this work to be successful, helping them reframe their definition of bullying where needed, and teachers will need to reflect critically upon their own definition and consider how it might be broadened and refined. Only then can school staff and pupils select the most appropriate type of anti-bullying policy. The House of Commons Education and Skills Committee (2007) and OFSTED (2003) have acknowledged that gaining pupils' views is of paramount importance in effectively addressing bullying at school. Involving pupils in collaborative work, such as research, is one way towards hearing their voices and breaking down the barriers between adults and children imposed by the existing power hierarchy (O'Brien and Moules, 2007).

A sense of ownership of this definition could encourage pupils to be more proactive in relaying the anti-bullying message throughout their school. Furthermore, if the definition promotes school staff as people who listen to the views of children, and take them seriously, it is possible that pupils will be encouraged to come forward if and when bullying occurs. Equally, if coming forward is promoted, then school staff will need to be more effective in dealing with bullying complaints and work within the definition of bullying decided by the school. The definition will also need to be revisited as teachers and children build their experiences of it in operation. It should not be considered as an 'add-on' to the already demanding curriculum but should be embedded within it. Nor should collaboration between staff and pupils be for 'bright' pupils only. Involvement in developing definitions and policies, as well as revisiting them, should be voluntary but participation should be wholeheartedly and persistently encouraged for all members of the school.

In reviewing anti-bullying initiatives it can be argued that no single perspective has all the answers (Rigby, 2004). As a conceptual aid, the various initiatives have been arranged figuratively in Figure 1.

At one end of this spectrum, bullying is tackled from the restorative justice viewpoint. This stance recognises that some children are more likely to be involved in bullying behaviour as a result of their individual characters (Rigby, 2003). This approach holds bullies to account and implements penalties for their behaviour but does not exclude them from their environment. Furthermore, it allows the victims of bullying to 'tell their story' in a supportive way (Rigby, 2003). At the other end, the whole-school approach is based on shared values, beliefs and attitudes within the school community. Elliott (2002) argues that this approach, along with an effective anti-bullying policy, is the most effective way to reduce the problem. It can be 
Figure 1: Range of initiatives used to tackle bullying

\begin{tabular}{c|c|c|c|c|}
$\begin{array}{c}\text { Restorative } \\
\text { justice }\end{array}$ & $\begin{array}{c}\text { Support group } \\
\text { method }\end{array}$ & Bully courts & Phole-school \\
approach
\end{tabular}

initiated by staff, parents or students and, once in place, it is difficult for bullying to continue because of joint working by the school and community to promote the message that such behaviour will not be tolerated (Elliott, 2002). However, this model is only one way to view anti-bullying initiatives. Some would argue that restorative justice should not be seen as 'punitive', nor should it be regarded as being at the other end of the spectrum from 'studentand teacher-led' approaches (see, for example, Hopkins, 2004; Cowie and Jennifer, 2008).

Figure 1 indicates that a broad range of models are currently in use and schools may wonder which one would be best for them. In terms of effectiveness, the evidence on what would work in a particular school remains patchy. A wide range of variables must be considered and, so too, the cultural context in which a model is introduced because this will have an effect on its implementation and resultant effectiveness. Despite the array of approaches available to tackle bullying, schools are still unsure how to handle this problem. Camodeca and Goossens (2005) suggest several reasons for this, including the possibility that effective interventions have yet to be designed or that current ones do not address the problem correctly. Furthermore, they suggest that it is quite likely that interventions have been designed by adults without any input from children and one way to find out more about their effectiveness is to ask those on the receiving end. This SR suggests that there are discrepancies in how pupils and teachers define bullying and, as a result, it is possible that anti-bullying policies are not working as well as they might. This could be linked to the fact that including pupils in decision making is still not given sufficient weight in some schools.

The participation of children in decision making about matters in their own lives is stressed by Article 12 of the UNCRC, and is contributing to changes in the social, cultural and economic conditions of children's lives all over the world (Willow, 2002; Prout, 2005). In the UK, the principle of participation is embedded in the 1989 Children Act and Every child matters: Change for children (DfES et al, 2004). However, in practice, participation may at times become little more than consultation. 'Consultation' implies that children are asked for their opinion because it is believed that they have relevant and important views to share on a topic (Flutter and Rudduck, 2004). 'Participation' is about finding ways to include their views in decision-making processes, taking into account what is feasible within the institutional context (Moules, 2005). Participation activities that amount to little more than consultation can send the message that a low value is placed on the children's views (Phillips, 2000), and children involved in projects where they have no real power will quickly become disillusioned and perceive their efforts to be worthless (Moules and O'Brien, 2007). For example, Rigby and Bagshaw (2003) report the difficulties they found in using a whole-school approach within a secondary school. They estimate that, in their sample of over 7,000 students from 75 Australian secondary schools, approximately $40 \%$ of students are either actively against collaborating with teachers to reduce bullying at school or are unsure about whether or not they want to collaborate. This finding might be linked to how pupils had been previously involved, perhaps indicating the need for a much more radical shift in how children are engaged in decision making.

Although there will be commonalities across schools in terms of their definitions of bullying, there are also likely to be differences. This may be because of particular demographic factors, such as gender, ethnicity or disability, that characterise a school or local education 
authority where similar schools are based. Consequently, what will work in one school may not necessarily work in another. Byron $(2008, \mathrm{p55})$ argues that defining bullying can lead to a better grasp of proportionality: for example, what is considered bullying in one incident might not be so in another (mild teasing, for example). It is therefore a recommendation of this SR that individual schools set their own bullying definitions, taking account of these similarities and differences. Campbell (2005, p72) suggests that:

each policy needs to be individualised for that school and not taken in whole from another school. The process or the journey of making the policy is as important as the end product. Perhaps for some schools its inclusion could be a useful revision to their existing policies. Additionally, unless the policy is translated into transparent daily use bullying will not be reduced.

Including both pupils and teachers in a research project to define bullying and develop a policy for their school appears to have considerable merit. Authorities are not simply telling the school community about a new definition or policy; they are involving key stakeholders, and without children's perspectives, schools cannot devise an inclusive definition of what constitutes bullying. Involving children in research, as 'co-researchers' rather than participants or research subjects, is a fairly new phenomenon. Traditionally, evidence was drawn from studies involving children, but it was the researchers' perspective in relation to what counts as evidence that was given priority (Flutter and Rudduck, 2004). The tenets of 'scientific' research served to devalue the experience of research participants, as researchers argued that they were more objective and thus better equipped to interpret such experiences (Beresford, 2006). Many service users firmly dispute this notion and propose that the shorter the distance between direct experience and its interpretation, the less distorted and more accurate the resulting knowledge is likely to be (Beresford, 2006). While children need protection, this can be overplayed by adults: some believe that they can represent a child's view without ever asking her or him directly because they 'know' what is in the child's best interest (Moules and O'Brien, 2007). Even when the child's voice is heard it can sometimes be ignored by adults who believe that they constitute the more reliable source of information (Moules and O'Brien, 2007). However, such beliefs are now much less likely to remain uncontested because 'Inquiry must begin with the experiences, perspectives and agenda for inquiry of those whose personal experience is at the centre of the enterprise' (Winter and Munn-Giddings, 2001, p57).

There is a need to train school staff about anti-bullying policies and practices. Campbell (2005), in his Australian study on cyber bullying, proposes that enhancing knowledge about this modern phenomenon should be an aspect of teacher induction and professional development. This SR recommends that knowledge regarding all forms of bullying, as well as 'what works' in tackling the problem, should be an integral part of teachers' professional development.

The studies included in the SR, in addition to those in the wider literature, reveal that teachers will not necessarily define bullying in the same way as pupils. Arguably, teachers need to be more aware of what it is that pupils are fearful of in school and, in turn, provide them with a safe learning environment, in line with Every child matters (DfES et al, 2004). Furthermore, teachers need to be more confident in how they deal with aspects of bullying, and training needs to be made available for this. Although a plethora of training manuals and materials are available for schools and teachers, Boulton and Flemington (1996) point out that staff could feel overwhelmed by these resources. It is therefore important for schools to be selective and to consider carefully what approach to intervention they need to adopt.

\section{Conclusion}

Findings from this study make a modest yet worthwhile contribution to the debate about bullying definitions and anti-bullying polices. The conceptual framework described by Naylor et al (2006) was used to consider findings from a further four studies, and an additional three themes were identified: sexualised bullying, focus on difference, and coercion. Differences between teachers' and pupils' definitions of bullying may be significant in understanding why anti-bullying strategies are less effective than they might be and also provide a challenge for securing a whole-school approach. A collaborative research project for schools is therefore 
proposed in which both pupils and teachers are fully involved in defining bullying. Once a definition is agreed, all stakeholders could be included in decisions about the type of antibullying policy best for the school. Such a process would promote the importance of listening to the views of children and, indeed, of teachers. A sense of ownership might be forthcoming from such collaboration and this could encourage pupils to be more proactive in promoting the anti-bullying message throughout their schools. Furthermore, if school staff are seen as people who listen to the views of children and take them seriously, it is more likely that pupils will be encouraged to come forward if and when bullying takes place. Finally, training needs to be provided for teachers so that they are more confident about dealing with the various aspects of bullying.

\section{References}

Alexander, L., Currie, C. and Mellor, A. (2004) Bullying: Health, well-being, and risk behaviours, Health Behaviour in School-Aged Children: Briefing Paper 10, Edinburgh: Child and Adolescent Research Unit, University of Edinburgh, www.education.ed.ac.uk/cahru/publications/factsheets downloads/BriefingPaper 10. pdf

Attree, P. (2004) 'Growing up in disadvantage: a systematic review of the qualitative evidence', Child: Care, Health \& Development, vol 30, no 6, pp 679-89.

BBC News (2005) 'Schools "in denial” over bullying', 13 November, http://news.bbc.co.uk/1/hi/uk/4433460.stm

Beresford, P. (2006) 'Making connections with direct experience: from the Western Front to user-controlled research', Educational Action Research, vol 14, no 2, pp 161-9.

Beverley, C., Edmunds-Otter, M. and Booth, A. (2006) 'Systematic reviews and secondary research', in K. Gerrish and A. Lacey (eds) The research process in nursing, Oxford: Blackwell, pp 316-34.

Booth, A. (2006) 'Critical appraisal of the evidence', in K. Gerrish and A. Lacey (eds) The research process in nursing, Oxford: Blackweel, pp 107-22.

Boulton, M.J. (1997) 'Teachers' views on bullying: definitions, attitudes and ability to cope'. British Journal of Educational Psychology, vol 67, no 2, pp 223-33.

Boulton, M.J. and Flemington, I. (1996) 'The effects of a short video intervention on secondary school pupils' involvement in definitions of and attitudes towards bullying', School Psychology International, vol 17, no 4, pp 331-45.

Boulton, M.J., Trueman, M. and Flemington, I. (2002) 'Associations between secondary school pupils' definitions of bullying, attitudes towards bullying and tendencies to engage in bullying: age and sex differences', Educational Studies, vol 28, no 4, pp $353-70$.

Byrne, B. (1994) Coping with bullying in schools, London: Cassell.

Byrne, M. (2001) 'Data analysis strategies for qualitative research', AORN Journal, vol 74, no 6, pp 904-5.

Byron, T. (2008) Safer children in a digital world: The report of the Byron Review, Nottingham: Department for Children, Schools and Families, and the Department for Culture, Media and Sport.

Camodeca, M. and Goossens, F.A. (2005) 'Children's opinions on effective strategies to cope with bullying: the importance of bullying role and perspective', Educational Research, vol 47, no 1, pp 93-105.

Campbell, M.A. (2005) 'Cyber bullying: on old problem in a new guise?', Australian Journal of Guidance and Counselling, vol 15, no 1, pp 68-76.

Cowie, H. and Jennifer, D. (2008) New perspectives on bullying, Maidenhead: Open University Press.

Craig, W., Henderson,K. and Murphy, J.G. (2000) 'Prospective teachers' attitudes toward bullying and victimization', School Psychology International, vol 21, no 1, pp 5-21.

Critical Reviews Advisory Group (1996) Introduction to systematic reviews, Sheffield: Sheffield University, School for Health and Related Research, ScHARR Library, http://www.shef.ac.uk/scharr/ir/intro.doc

DfES (Department for Education and Skills) (2004) Every child matters: Change for children, London: DfES, http://publications.everychildmatters.gov.uk/eOrderingDownload/DfES10812004.pdf 
Dixon-Woods, M., Agarwal, S., Jones, D., Young, B. and Sutton, A. (2005b) 'Synthesising qualitative and quantitative evidence: a review of possible methods', Journal of Health Services Research and Policy, vol 10, no 1, pp 45-51.

Dixon-Woods, M., Booth, A., Jones, D., Miller, T., Shaw, R., Smith, J.A., Sutton, A. and Young, B. (2005a) How can systematic reviews incorporate qualitative research?, Methods Briefing 6, Manchester: ESRC Research Methods Programmer, http://www.ccsr.ac.uk/methods/publications/documents/dixonwoods.pdf

Elliott, M. (2002) 'A whole school approach to bullying', in M. Elliott (ed) Bullying: A practical guide to coping for schools ( $3^{\text {rd }}$ edition), London: Pearson Education, pp 303-16.

EPPI-Centre, http://eppi.ioe.ac.uk/cms/Portals/0/PDF\%20reviews\%20and\%20summaries/EPPICentre Review Methods 11.pdf

Evans, J., and Benefield, P. (2001) 'Systematic reviews of educational research: does the medical model fit?', British Educational Research Journal, vol 27, no 5, pp 527-41.

Flutter, J. and Rudduck, J. (2004) Consulting pupils: What's in it for schools?, London: Routledge.

Furniss, C. (2000) 'Bullying in schools: it's not a crime - is it?', Education and the Law, vol 12, no 1, pp 9-29.

Glover, D., Gough, G., Johnson, M. and Cartwright, N. (2000) 'Bullying in 25 secondary schools: incidence, impact and intervention', Educational Research, vol 42, no 2, pp 141-56.

Harden, A., Garcia, J., Oliver, S., Rees, R., Shepherd, J., Brunton, G. and Oakley, A. (2004) 'Applying systematic review methods to studies of people's views: an example from public health research', Journey of Epidemiology and Community Health, vol 58, no 9, pp 794-800.

HM Treasury (2003) Every child matters: Presented to Parliament by the Chief Secretary to the Treasury by Command of Her Majesty September 2003, Cm 5680, London: The Stationery www.everychildmatters.gov.uk/ content/documents/EveryChildMatters.pdf

Hodgson, D. (1996) Young people's participation in social work planning: A resource pack, London: National Children's Bureau.

Hopkins, B. (2004) Just schools: A whole school approach to restorative justice, London: Jessica Kingsley Publishers.

House of Commons Education and Skills Committee (2007) Bullying: Third report of Session 2006-07, HC 85, London: The Stationery Office, www.publications.parliament.uk/pa/cm200607/cmselect/cmeduski/85/85.pdf

Jennifer, D., Cowie, H. and Bray, D. (2006) "Bully Dance": animation as a tool for conflict resolution', Pastoral Care in Education: An International Journal of Personal, Social and Emotional Development, vol 24, no 1, pp 27-32.

Juvonen, J., Graham, S. and Schuster, M.A. (2003) 'Bullying among young adolescents: the strong, the weak and the troubled', Pediatrics, vol 112, no 6, pp 1231-7.

Khan, K.S., Ter Riet, G., Popay, J., Nixon, J. and Kleijnen, J. (2001) 'Stage II conducting the review, Phase 5 study quality assessment', in Undertaking systematic review of research on effectiveness: CRD's guidance for those carrying out or commissioning reviews, CRD Report 4 ( $2^{\text {nd }}$ edition), York: York University, Centre for Reviews and Dissemination, www.york.ac.uk/inst/crd/report4.htm

Lee, C. (2006) 'Exploring teachers' definitions of bullying', Emotional and Behavioural Difficulties, vol 11, no 1, pp 61-75.

Lines, D. (1999) 'Secondary pupils' experiences of name-calling behaviour', Pastoral Care in Education, vol 17, no 1, pp 23-31.

Margarey, J.M. (2001) 'Elements of a systematic review', International Journal of Nursing Practice, vol 7, no 6, pp 376-82.

Monks, C.P. and Smith, P.K. (2006) 'Definitions of bullying: age differences in understanding of the term, and the role of experience', British Journal of Developmental Psychology, vol 24, no 4, pp 801-21.

Morrison, B. (2002) Bullying and victimisation in schools: A restorative justice approach, Trends and Issues in Crime and Criminal Justice 219, Canberra: Australian Institute of Criminology, www.popcenter.org/problems/bullying/PDFs/ti219.pdf 
Moules, T. (2005) 'Whose quality is it? Children and young people's participation in monitoring the quality of care in hospital: a participatory research study', Unpublished $\mathrm{PhD}$ thesis, Anglia Ruskin University, Chelmsford, UK.

Moules, T. and O'Brien, N. (2007) 'The child's perspective and service delivery', in D.DeBell (ed) Public health practice and the school-age population, London: Hodder Arnold, pp 259-78.

Naylor, P., Cowie, H. and Delrey, R. (2001) 'Coping strategies for secondary school children in response to being bullied', Child Psychology and Psychiatry Review, vol 6, no 3, pp 114-20.

Naylor, P., Cowie, H., Cossin, F., de Bettencourt, R. and Lemme, F. (2006) 'Teachers' and pupils' definitions of bullying', British Journal of Educational Psychology, vol 76, no 3, pp 553-76.

O'Brien, N. and Moules, T. (2007) 'So round the spiral again: a reflective participatory research project with children and young people', Educational Action Research Journal, vol 15, no 3, pp 385-402.

OFSTED (Office for Standards in Education) (2003) Bullying: Effective action in secondary schools, HMI 465, London: OFSTED, http://www.ofsted.gov.uk/Ofsted-home/Formsand-guidance/Browse-all-by/Other/General/Bullying-effective-action-in-secondaryschools

O'Kane, C. (2000) 'The development of participatory techniques: facilitating children's views about decisions which affect them', in P. Christensen and A. James (eds) Research with children: Perspectives and practices, London: Falmer Press.

Oliver, C. and Candappa, M. (2003) Tackling bullying: Listening to the views of children and young people, Research Report RR400, London: DfES, http://www.dcsf.gov.uk/research/data/uploadfiles/RR400.pdf

Olweus, D. (1995) 'Bullying or peer abuse at school: facts and intervention', Current Directions in Psychological Science, vol 4, no 6, pp 196-200.

Petticrew, M. and Roberts, H. (2006) Systematic reviews in the social sciences: A practical guide, Oxford: Blackwell.

Phillips, B. (2000) 'The end of paternalism? Child beneficiary participation and project effectiveness', Unpublished Masters' dissertation, Institute of Social Studies, The Hague, the Netherlands.

Popay, J., Roberts, H., Sowden, A., Petticrew, M., Arai, L., Rodgers, M., Britten, N., Roen, K. and Duffy, S. (2006) Guidance on the conduct of narrative synthesis in systematic reviews, Manchester: ESRC Research Methods Programme.

Prout, A. (ed) (2005) The future of childhood: Toward the interdisciplinary study of children, Oxford: Routledge.

Rigby, K. (2003) 'Consequences of bullying in schools', Canadian Journal of Psychiatry, vol 48, no 9, pp 583-90.

Rigby, K. (2004) 'Addressing bullying in schools: theoretical perspectives and their implications', School Psychology International, vol 25, no 3, pp 287-300.

Rigby, K. and Bagshaw, D. (2003) 'Prospects of adolescent students collaborating with teachers in addressing issues of bullying and conflict in schools', Educational Research, vol 23, no 5, pp 535-46.

Smith, P, and Samara, M. (2003) Evaluation of the DfES Anti-Bullying Pack, Research Brief RBX06-03, London: DfES, www.dcsf.gov.uk/research/data/uploadfiles/RBX06-03.pdf

Smith, P.K. (1999) 'England and Wales', in P.K. Smith, Y. Morita, J.Junger-Tas, D. Olweus, R. Catalano and P. Slee (eds) The nature of school bullying: A cross-national perspective, London: Routledge, pp 68-90.

Smith, P.K. and Shu, S. (2000) 'What good schools can do about bullying: findings from a survey in English schools after a decade or research and action', Childhood, vol 7, no 2, pp 193-212.

Smith, P.K., Cowie, H., Olafsson, R.F. and Liefooghe, A.P.D. (2002) 'Definitions of bullying: a comparison of terms used, and age and gender differences, in a fourteen-country international comparison', Child Development, vol 73, no 4, pp 1119-33.

Smorti, A., Menesini, E., and Smith, P.K. (2003) Parents' definitions of children's bullying in a five country comparison', Journal of Cross-Cultural Psychology, vol 34, 417-32.

Sullivan, K., Cleary, M. and Mark, G. (2004) Bullying in secondary schools: What it looks like and how to manage it, London: Paul Chapman Publishing. 
Thoburn, J. (1992) Participation in practice: Involving families in child protection, Norwich: University of East Anglia, Social Work Development Unit.

Thomson, P. and Gunter, H. (unpublished) 'Researching bullying with students: a lens on everyday life in an innovative school', Subsequently published under this title in International Journal of Inclusive Education, 2008, vol 12, no 2, pp 185-200.

Torgerson, C. (2003) Systematic reviews, London: Continuum International Publishing Group.

Willow, C. (2002) Participation in practice: Children and young people as partners in change, London: The Children's Society.

Winter, R. and Munn-Giddings, C. (2001) A handbook for action research in health and social care, London: Routledge.

Wolke, D., Woods, S., Stanford, K. and Schulz, H. (2001) 'Bullying and victimization of primary school children in England and Germany: prevalence and school factors', British Journal of Psychology, vol 92, no 4, pp 673-96.

Woods, S. and Wolke, D. (2003) 'Does the content of anti-bullying policies inform us about the prevalence of direct and relational bullying behaviour in primary schools?', Educational Psychology, vol 23, no 4, pp 381-401. 